\title{
Virulence of Xanthomonas translucens pv. poae Isolated from Poa annua
}

\author{
Arielle Chaves and Nathaniel Mitkowski* \\ Department of Plant Sciences, University of Rhode Island, 9 E. Alumni Ave., Suite 7, Kingston, RI, USA \\ (Received on August 17, 2012; Revised on December 5, 2012; Accepted on December 16, 2012)
}

Bacterial wilt is a vascular wilt disease caused by Xanthomonas translucens pv. poae that infects Poa annua, a grass that is commonly found on golf course greens throughout the world. Bacterial wilt causes symptoms of etiolation, wilting, and foliar necrosis. The damage is most prevalent during the summer and the pathogen can kill turf under conditions optimal for disease development. Fifteen isolates of $X$. translucens pv. poae were collected from northern regions in the United States and tested for virulence against $P$. annua. All 15 isolates were pathogenic on $P$. annua, but demonstrated variable levels of virulence when inoculated onto $P$. annua under greenhouse conditions. The isolates were divided into two virulence groups. The first group containing four isolates generally resulted in less than $\mathbf{4 0 \%}$ mortality following inoculation. The second group, containing the other eleven isolates, produced between 90 and $100 \%$ mortality following inoculation. These results suggest that differences in the virulence of bacterial populations present on a golf course may result in more or less severe amounts of observed disease.

Keywords : annual bluegrass, bacterial wilt, golf course putting greens, etiolation

In recent years, bacterial wilt of both Poa annua and Agrostis stolonifera have become major disease issues for golf course superintendents in the United States. Bacterial wilt of annual bluegrass (Poa апnиa) is caused by Xanthomonas translucens pv. poae (Mitkowski et al., 2005) and the bacterial wilt of bentgrass is caused by Acidovorax avenae var. avenae (Giordano et al., 2010), although outbreaks of bacterial wilt of bentgrass have been caused by $X$. translucens pv. graminis have been reported (Roberts and Vargas, 1984). During the summer of 2010, both pathogens caused significant damage across the northeastern United States. While the occurrence of $A$. avenae var. avenae on turfgrass in the United States is a relatively new development, $X$. translucens pv. poae was first reported in

\footnotetext{
*Corresponding author.

Phone) +401-874-5996, FAX) +401-874-2494

E-mail)mitkowski@uri.edu
}

the US in 1985 (Roberts et al., 1985). Since then it has been reported throughout the eastern seaboard and as far west as Montana (Mitkowski, 2005). Additionally, this disease has been described in Japan, the pathogen has been isolated from Europe and it likely to be present anywhere the host is found (Nishino et al., 1995).

$X$. translucens pv. poae is particularly aggressive on golf course putting greens because it requires a wound to gain entry into the plant. Most golf courses mow putting greens every day, providing both the required wound and an efficient delivery system through mower blades. Bacteria enter wounded leaves and spread into the plant crowns, resulting in wilting and eventual plant death. Initial symptoms often include etiolation, especially on golf course putting greens (Fig. 1). The disease is most severe when plants are under environmental stress (such as low cutting heights, soil compaction and shade), are growing slowly and temperatures are high (Mitkowski et al., 2005). While closely mown turf is particularly susceptible, the pathogen can kill plants grown at a height of $2 \mathrm{~cm}$ or more if inoculated with bacterial concentrations higher than $10^{7}$ cfu/ml (Fig. 2).

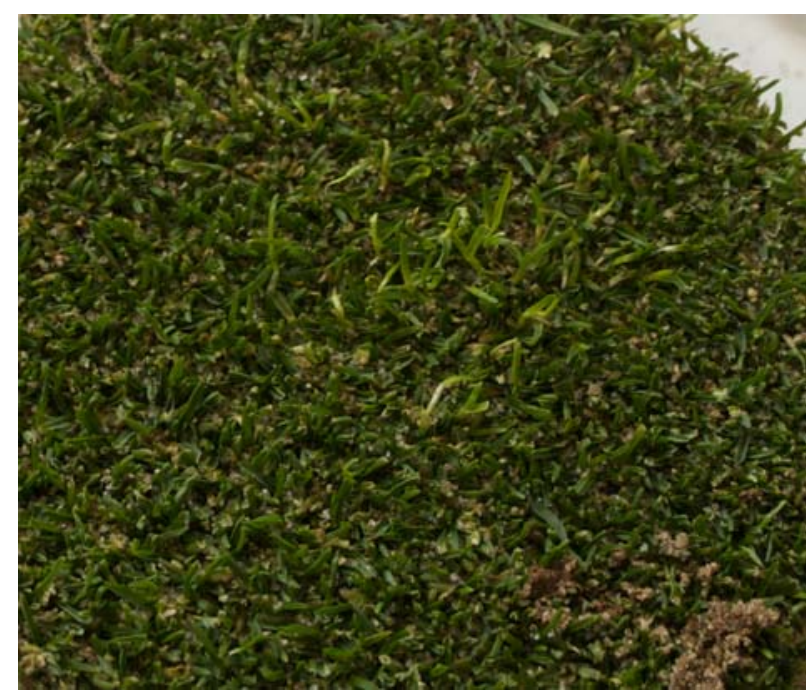

Fig. 1. Poa annua plants from a golf course putting green sample displaying the initial symptoms of etiolation, typical of $X$. translucens pv. poae infection in the field. Wilting, decline and death in 1-2 cm spots usually follow. 


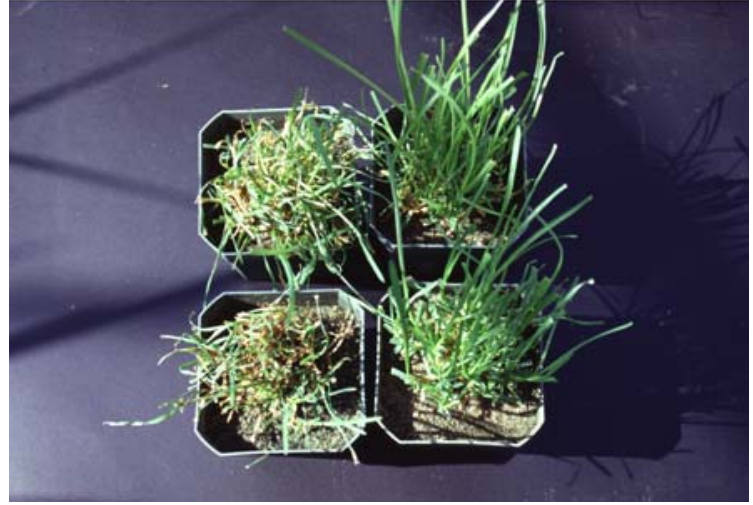

Fig. 2. Poa annua plants inoculated with $10^{8} \mathrm{cfu} / \mathrm{ml}$ of $X$. translucens pv. poae (left) displaying substantial decline and wilting, one week after inoculation, compared to water controls (right).

Despite the ability of $X$. translucens pv. poae to kill plants in the field, it has been observed that not all putting greens where the pathogen is present display disease symptoms suffer catastrophic turf losses. While there are many possible environmental factors that can influence the course of a bacterial wilt infection, it is likely that host and pathogen genetics play a role in disease. The primary goal of our research was to determine if differences in virulence could be identified between isolates of $X$. translucens pv. poae and to find a possible explanation for why some locations experience more severe outbreaks of the disease than other locations.

In this study, we examined fifteen different isolates of $X$. translucens pv. poae for variable levels of virulence on their primary host, Poa annua var. апnиa. In addition, the 16S23S rDNA region of 46 isolates of $X$. translucens (including the fifteen isolates identified as $X$. translucens pv. poae and used in this study) was sequenced in order to further confirm the identity of the isolates used in this project.

$X$. translucens pv. poae was isolated from symptomatic turf samples that were sent to the University of Rhode Island (URI) Turf Diagnostic Lab. In each case, X. translucens pv. poae was isolated from etiolated leaf blades that produced copious amounts of bacterial streaming from the vascular bundles when cut and observed under $40 \times$ power. The bacteria were then isolated by cutting the additional etiolated leaves into $2-3 \mathrm{~mm}$ pieces and surface sterilizing them in a solution of $0.6 \%$ sodium hypchlorite for $2 \mathrm{~min}$. The leaf pieces were transferred to sterile distilled water to rinse off the bleach solution and the leaf pieces were then plated on to YDC plates (10 g/l yeast extract; Difco SparksMD, USA, $20 \mathrm{~g} / 1$ dextrose, $20 \mathrm{~g} / \mathrm{l}$ calcium carbonate, and $15 \mathrm{~g} / \mathrm{l}$ agar) (Schaad, 1980). Forceps and inoculating needles were dipped in $70 \%$ ethanol and flamed to sterilize. Isolation plates were incubated for $3-4$ days in a $28^{\circ} \mathrm{C}$ incubator. Yellow mucoid bacterial growth was transferred to a new YDC plates using a sterile inoculating needle. Individual colonies were isolated using isolation streaking. Isolates were then placed in $50 \%$ glycerol in a $-80^{\circ} \mathrm{C}$ freezer for long-term storage. Table 1 lists the $X$. translucens pv. poae isolates used in this study, as well as the date of isolation and location from which the samples were obtained.

Isolate Identification. All of the isolates used in this study were identified as $X$. translucens pv. poae based on several methods, including Gram staining (Gram-negative), colony morphology (yellow, mucoid colonies produced on YDC), pathogenicity (the ability to cause wilting and necrosis on Poa аппиа), BLAST searches of the sequences of $16 \mathrm{~S}$ ribosomal DNA and a phylogenetic comparison of partial $16 \mathrm{~S}$, the complete intergenic spacer region, and partial $23 \mathrm{~S}$ ribosomal DNA sequences with other pathovars of $X$. translucens.

PCR used to confirm the identity of the bacterial isolates utilized the following ITS primer pairs: Xan1 (5'GGAGAG TTAGATCTTGGCTCAG-3') and Xan2 (CCGGGTTTCC CCATTCGG-3'); Xan3 (5'-CCCGGTGTAGCAAATG-3') and Xan4 (5'-ATGCAGGTTACTTGTCAGGACG-3'). Pri-

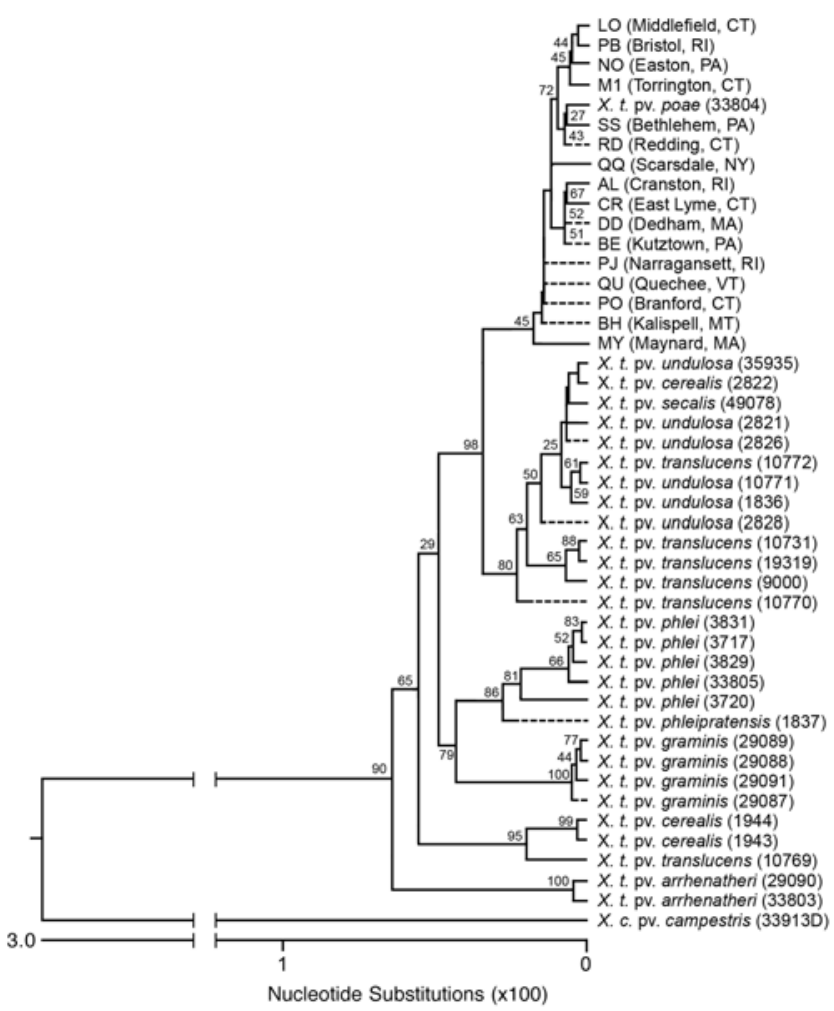

Fig. 3. MegAlign 8.0 generated dendrogram of 16S-23S rDNA sequences from all 46 strains of Xanthomonas used in this study, based on Clustal W (slow/accurate alignment). Bootstrap values are based on 1000 replications. Values of less than 25 are not included in the figure. 
Table 1. List of isolates examined in this study, including pathovar, host, location and date of isolation

\begin{tabular}{|c|c|c|c|c|}
\hline Accession & Xanthomonas translucens pathovar ${ }^{2}$ & Location & Host & Date Collected \\
\hline M1 & X.t.pv.poae & US (Torrington, CT) & Poa annua var. апnua & $7 / 2001$ \\
\hline $\mathrm{AL}$ & X.t. pv.poae & US (Cranston RI) & Pоа аппиа var. аппиа & $8 / 2003$ \\
\hline LO & $X . t$. pv.poae & US (Middlefield, CT) & Poa anпua var. аппиа & $5 / 20 / 04$ \\
\hline QQ & $X . t$. pv.poae & US (Scarsdale, NY) & Poа аппиа var. аппиа & $6 / 19 / 04$ \\
\hline MY & X.t.pv.poae & US (Maynard, MA) & Pоа аппиа var. аппиа & $7 / 29 / 04$ \\
\hline $\mathrm{BH}$ & $X . t$. pv.poae & US (Kalispell, MT) & Poa annua var. annua & $8 / 3 / 04$ \\
\hline $\mathrm{CR}$ & X.t.pv.poae & US (East Lyme, CT) & Pоа аппиа var. аппиа & $8 / 17 / 04$ \\
\hline PJ & $X . t$. pv.poae & US (Narragansett, RI) & Poa anпua var. аппиа & $9 / 2 / 04$ \\
\hline $\mathrm{PO}$ & $X . t$. pv.poae & US (Branford, CT) & Poa annua var. annua & $6 / 16 / 05$ \\
\hline DD & $X . t$. pv.poae & US (Dedham, MA) & Poa anпua var. аппиа & $6 / 21 / 05$ \\
\hline SS & $X . t$. pv.poae & US (Bethlehem, PA) & Pоа аппиа var. аппиа & $8 / 13 / 05$ \\
\hline QU & X.t.pv.poae & US (Quechee, VT) & Pоа аппиа var. аппиа & $9 / 10 / 05$ \\
\hline $\mathrm{BE}$ & $X . t$. pv.poae & US (Easton, PA) & Poа аппиа var. аппиа & $10 / 13 / 05$ \\
\hline NO & X.t.pv.poae & US (Kutztown, PA) & Pоа аппиа var. аппиа & $6 / 5 / 06$ \\
\hline PB & X.t.pv.poae & US (Bristol, RI) & Pоа аппиа var. аппиа & $6 / 26 / 07$ \\
\hline $\mathrm{RD}$ & $X . t$. pv.poae & US (Redding, CT) & Poa annua var. annua & $11 / 27 / 07$ \\
\hline ATCC $33804^{y}$ & X.t.pv.poae & Switzerland & Poa trivialis & 1978 \\
\hline ATCC 29090 & $X . t$. pv. arrhenatheri & Switzerland & Arrhenatherum elatius & 1973 \\
\hline ATCC 33803 & $X . t$. pv. arrhenatheri & Switzerland & Arrhenatherum elatius & 1978 \\
\hline NCPPB 1943 & $X . t$. pv. cerealis & US & Hordeum vulgare & 1942 \\
\hline NCPPB $1944^{y}$ & $X . t$. pv. cerealis & US & Bromus inermis & 1941 \\
\hline ATCC 29087 & X.t. pv. graminis & Switzerland & Dactylis glomerata & 1973 \\
\hline ATCC 29088 & $X . t$. pv. graminis & Switzerland & Lolium multiflorum & 1973 \\
\hline ATCC 29089 & $X . t$. pv. graminis & Switzerland & Lolium multiflorum & 1973 \\
\hline ATCC $29091^{y}$ & $X . t$. pv. graminis & Switzerland & Dactylis glomerata & 1973 \\
\hline ATCC 33805 & X.t.pv.phlei & Norway & Phleum pratense & 1978 \\
\hline NCPPB 3717 & X.t.pv.phlei & Norway & Phleum pratense & 1980 \\
\hline NCPPB 3720 & X.t.pv.phlei & Norway & Phleum pratense & 1978 \\
\hline NCPPB 3829 & X.t.pv.phlei & Norway & Phleum pratense & 1978 \\
\hline NCPPB 3831 & $X . t . \mathrm{pv}$. phlei & Norway & Phleum pratense & 1980 \\
\hline NCPPB $1837^{y}$ & $X . t$. pv. phleipratensis & US & Phleum pratense & 1942 \\
\hline NCPPB $2822^{y}$ & X.t. pv. secalis (X.t. pv. undulosa) & unknown & Secale ceralis & 1966 \\
\hline ATCC 49078 & X.t. pv. secalis (X.t. pv. undulosa) & unknown & Secale ceralis & unknown \\
\hline ATCC 9000 & $X . t$. pv. translucens & Canada (Manitoba) & Hordeum vulgare & 1934 \\
\hline ATCC 10731 & X.t. pv. translucens & unknown & Hordeum vulgare & unknown \\
\hline ATCC 10769 & X.t. pv. translucens (X.t. pv. cerealis) & unknown & Agropyron repens & unknown \\
\hline ATCC 10770 & $X . t$. pv. translucens & unknown & Hordeum vulgare & unknown \\
\hline ATCC 10772 & X.t. pv. translucens (X.t. pv. undulosa) & unknown & Secale ceralis & unknown \\
\hline ATCC $19319^{y}$ & $X . t$. pv. translucens & US & Hordeum vulgare & 1933 \\
\hline ATCC 10771 & X.t. pv. undulosa & unknown & Triticum spp. & unknown \\
\hline ATCC 35935 & $X . t$. pv. undulosa & Canada & Triticum turgidum & 1975 \\
\hline NCPPB 1836 & $X . t$. pv. undulosa & US & Secale ceralis & 1942 \\
\hline NCPPB 2826 & X.t. pv. undulosa & Canada & Triticum sp. $\times$ Secale sp. & 1968 \\
\hline NCPPB 2821 & $X . t$. pv. undulosa & Canada & Triticum durum & 1966 \\
\hline NCPPB 2828 & $X . t$. pv. undulosa & Canada & Triticum aestivum & 1969 \\
\hline ATCC 33913 & $X$. campestris pv. campestris & United Kingdom & Brassica oleracea & 1957 \\
\hline
\end{tabular}

${ }^{\text {y }}$ Pathotype or neopathotype strain

${ }^{\mathrm{z}}$ Strain NCPPB 1836 originally received as $X$. transluceus pv. cerealis and ATCC 10771 originally received as $X$. transluceus pv. translucens but designated $X$. transluceus pv. undulosa per Rademaker et al. (12). Pathovars listed in parentheses are the pathovar group that the isolate most is most closely associated, based on rDNA phylogeny reported in this study. 
mers Xan 1 / Xan 2 (Jones, 2000) were used to amplify the outer 1,000 bp of the sequence, and primers Xan 3 / Xan 4 were used to amplify the inner $1,000 \mathrm{bp}$ of the sequence (Mitkowski et al., 2005). The four sequences were then combined to produce two sequences. PCR was performed as a $25 \mu \mathrm{l}$ reaction mixture containing $1 \mu \mathrm{l}$ of template DNA, $14 \mu \mathrm{l}$ of sterile distilled water, $2.5 \mu \mathrm{l}$ of $25 \mathrm{mM}$ $\mathrm{MgCl}_{2}, 2.5 \mu \mathrm{l}$ of $10 \times$ magnesium free buffer, $1.3 \mu \mathrm{l}$ of 200 $\mu \mathrm{M}$ dNTPs and $0.5 \mu \mathrm{l}$ each of $10 \mu \mathrm{M}$ primer. The PCR reaction tubes were placed into the thermal cycler at $94^{\circ} \mathrm{C}$ and then 0.5 units of Taq DNA polymerase (Promega Corp., Madison, WI, USA) were added to each tube. The thermocycler program consisted of: $1 \mathrm{~min}$ at $94^{\circ} \mathrm{C}, 1 \mathrm{~min}$ at $51^{\circ} \mathrm{C}$ and $2 \mathrm{~min}$ at $72^{\circ} \mathrm{C}$ repeated 25 times, followed by 5 min of extension at $72^{\circ} \mathrm{C}$. PCR products were purified using a QUIAquick PCR Purification Kit (Qiagen, Germantown, MD, USA). The DNA was sequenced at the URI Genomics Sequencing Center.

Consensus sequences from individual amplicons were produced using the SeqMan II module of LaserGene 8 (DNAStar, Madison, WI, USA). Alignments were checked for end-gap misalignment using the Clustal V protocol. BLAST nucleotide searches showed a Xanthomonas species as the closest match for each of the $X$. translucens pv. poae isolates, with a high level of probability (greater than 99\%).

Figure 3 depicts the phylogenetic tree created by comparing the $16 \mathrm{~S}$ ribosomal DNA of 46 different $X$. translucens pathovars, using sequence alignments produced by the slow-accurate Clustal W algorithm employed by MegAlign 8.0 (DNAStar, Madison, WI, USA). Isolates utilized in the phylogentic analysis were obtained by direct culturing or from the American Type Culture Collection (Manassas, VA, USA) or the National Collection of Plant Pathogenic Bacteria (York, UK). The URI X. translucens pv. poae isolates clustered together in a single branch, highly supported by bootstrap analysis, along with a Swiss isolate from Poa trivialis, indicating that the URI $X$. translucens pv. poae isolates are more closely related to each other than to any of the other $X$. translucens pathovars. Table 1 includes the complete list of $X$. translucens pathovars used to construct this phylogenetic tree along with the host plants from which they were isolated.

Mature $P$. annua plants were collected from around the URI campus, in Kingston, RI. The plants were potted into $1.5 \times 8$ inch $(3.1 \mathrm{~cm} \times 21 \mathrm{~cm})$ conetainers containing MetroMix 510 (Sungro Horticulture, Bellevue, WA, USA), a potting mix consisting of peat, vermiculite, and pine bark. The plants were grown in the greenhouse for 2-3 weeks prior to inoculation and none of the plants displayed any symptoms of bacterial wilt at the time of inoculation. The plants were clipped approximately two times per week to a height of $3-5 \mathrm{~cm}$ while in the greenhouse, prior to inoculation. The plants were fertilized once a week with Peter's professional fertilizer (20-10-20) diluted to $200 \mathrm{ppm}$ nitrogen with a Dosatron ferilizer injector.

Glycerol stocks were removed from the $-80^{\circ} \mathrm{C}$ freezer three days before starting bacterial cultures and were plated on to YDC. The cultures were grown in a $28^{\circ} \mathrm{C}$ incubator for 3 days. Each bacterial isolate was then streaked on to 10 YDC plates and grown for 4 days in a $28^{\circ} \mathrm{C}$ incubator in order to obtain a sufficient volume of inoculum. Each plate was flooded with $1 \mathrm{~mL}$ of a $0.9 \%$ sterile saline solution and the bacteria were harvested by scraping with a Nalgene Policeman (Nalgene Labware, ThermoFisher Scientific, Pittsburg, PA, USA). The bacterial solution was diluted with $0.9 \%$ sterile saline solution to approximately $10^{7}-10^{8}$ $\mathrm{cfu} / \mathrm{ml}$, which was determined initially using serial plate dilutions and determined in subsequent inoculations using $\mathrm{OD}_{600}$ values corresponding to the appropriate concentration. The plants were inoculated by clipping the leaf blades with scissors and then immediately dipping the cut leaf blades into the bacterial solution. The scissors were sterilized prior to inoculation by spraying with $70 \%$ ethanol and then wiping the scissors dry with a paper towel. The negative control was clipped with scissors without applying any bacterial inoculum. Five individual plants (one plant per container) were inoculated with each bacterial isolate, as well as an uninoculated control. The plants were placed in a growth chamber set at $28^{\circ} \mathrm{C}$ with continuous illumination immediately after inoculation immediately after inoculation. The plants remained in the growth chamber for approximately 3 weeks until they were rated. These virulence tests were repeated a total of three times in August 2008, September 2008, and January 2009.

The plants were rated approximately three weeks after inoculation by visually estimating the percentage of dead leaf tissue. A rating of 0 indicated no foliar necrosis, a rating of 100 indicated complete plant death, and a rating of $50 \%$ indicated approximately half of the leaves were dead on an individual plant. Data analysis was performed using ANOVA, and given a significant ANOVA $p$-value, the general linear model and the Waller-Duncan Comparison of Means in SPSS (Chicago, Il, USA) were then performed. Each of the three trials was analyzed separately. The sample size for each trial was five individual plants.

Two levels of virulence were observed among the $X$. translucens pv. poae isolates; highly virulent isolates that caused between 95 to $100 \%$ foliar necrosis and moderately virulent isolates that caused on average less than $40 \%$ foliar necrosis. The isolates from Torrington, Lyman Orchard, Alpine, and Cedar Ridge consistently caused less severe symptoms with averages of: $16 \%, 20 \% 27 \%$, and $37 \%$ necrosis, respectively. The other 11 isolates consistently caused a high level of disease with $90-100 \%$ mortality. 
Table 2. Percentage disease caused by multiple $X$. translucens pv. poae isolates when artificially inoculated on $P$. аппиа

\begin{tabular}{|c|c|c|c|c|}
\hline \multirow{2}{*}{ Isolate } & Trial 1 & Trial 2 & Trial 3 & Pooled Mean \\
\hline & $\%$ Disease & $\%$ Disease & $\%$ Disease & $\%$ Disease \\
\hline Water Control & $0 \mathrm{a}$ & $1.0 \mathrm{a}$ & $6.0 \mathrm{a}$ & $2.3 \mathrm{a}$ \\
\hline M1 & $28.0 \mathrm{bc}$ & $14.0 \mathrm{abc}$ & $6.0 \mathrm{a}$ & $16.0 \mathrm{ab}$ \\
\hline LO & $6.0 \mathrm{ab}$ & $27.0 \mathrm{bc}$ & $27.0 \mathrm{ab}$ & $20.0 \mathrm{~b}$ \\
\hline $\mathrm{AL}$ & $40.0 \mathrm{~cd}$ & $8.0 \mathrm{ab}$ & $33.0 \mathrm{~b}$ & $27.0 \mathrm{bc}$ \\
\hline CR & $58.0 \mathrm{c}$ & $31.0 \mathrm{c}$ & $24.0 \mathrm{ab}$ & $37.7 \mathrm{c}$ \\
\hline NO & $89.0 \mathrm{e}$ & $100 \mathrm{~d}$ & $100 \mathrm{c}$ & $96.3 \mathrm{~d}$ \\
\hline PO & $99.0 \mathrm{e}$ & $100 \mathrm{~d}$ & $100 \mathrm{c}$ & $99.7 \mathrm{~d}$ \\
\hline PB & $100 \mathrm{e}$ & $100 \mathrm{~d}$ & $100 \mathrm{c}$ & $100 \mathrm{~d}$ \\
\hline MY & $100 \mathrm{e}$ & $100 \mathrm{~d}$ & $100 \mathrm{c}$ & $100 \mathrm{~d}$ \\
\hline $\mathrm{BE}$ & $100 \mathrm{e}$ & $100 \mathrm{~d}$ & $100 \mathrm{c}$ & $100 \mathrm{~d}$ \\
\hline PJ & $100 \mathrm{e}$ & $99.0 \mathrm{~d}$ & $100 \mathrm{c}$ & $99.7 \mathrm{~d}$ \\
\hline SS & $100 \mathrm{e}$ & $100 \mathrm{~d}$ & $100 \mathrm{c}$ & $100 \mathrm{~d}$ \\
\hline QQ & $89.0 \mathrm{e}$ & $99.0 \mathrm{~d}$ & $100 \mathrm{c}$ & $96.0 \mathrm{~d}$ \\
\hline $\mathrm{BH}$ & $100 \mathrm{e}$ & $100 \mathrm{~d}$ & $100 \mathrm{c}$ & $100 \mathrm{~d}$ \\
\hline DD & $99.0 \mathrm{e}$ & $99.0 \mathrm{~d}$ & $99.0 \mathrm{c}$ & $99.3 \mathrm{~d}$ \\
\hline $\mathrm{RD}$ & $100 \mathrm{e}$ & $86.0 \mathrm{~d}$ & $97.0 \mathrm{c}$ & $94.3 \mathrm{~d}$ \\
\hline
\end{tabular}

Ratings were performed by visually estimating percent of dead leaves on individual plants (in some cases, plants began to tiller and thus had multiple stems that were considered a single plant). A rating of 100 indicates complete plant death, a rating of 50 indicates approximately half of the leaves were dead, and a rating of 0 indicates no death. Means within a column followed by the same letter are not statistically different according to the Waller-Duncan k-ratio t-test $(\mathrm{k}=100$, $p \leq 0.05)$

Table 2 lists the means and subset groupings for all three experiments, as well as an average for of the three experiments for each isolate.

These virulence differences suggest that disease may occur more severely in those locations where more virulent isolates are present. Despite these dramatic differences in disease expression, it is important to note that the results obtained from greenhouse experiments may not always mirror observations in the field. The concentrations of bacteria used to inoculate $P$. annua in the current study were extremely high. On a golf course putting green, even the most highly virulent isolates will not be present at these concentrations and consequently the level of mortality and observed diseases is likely to be far less. The environmental conditions utilized during this study were chosen to maximize the level of plant infection and disease potential. Therefore, even while we can experimentally detect different virulence phenotypes in the greenhouse, we may not be able to observe these differences under field conditions. In addition, the plants utilized in this study were taken from field locations and were not varietal, as is typical for most turfgrasses (which are usually synthetic varieties). While virulence differences between isolates were consistent in the current study in the greenhouse, genetic variation between plants in the field is likely to significantly contribute to differences in symptom expression on a golf course putting green that cannot be easily replicated in greenhouse trials.

Temperature clearly plays a significant role in the expression of bacterial wilt of $P$. аппиа. In previous work, the highest level of symptom expression was observed in $P$. annua infected with $X$. translucens at $32^{\circ} \mathrm{C}$, the next highest level of symptoms was observed at $26^{\circ} \mathrm{C}$ and the lowest levels of symptoms expression at $8^{\circ} \mathrm{C}$ and $14^{\circ} \mathrm{C}$ (Kalmowitz, 1993). In the current study, inoculation and incubation was undertaken at $28^{\circ} \mathrm{C}$. A greater difference in the range of virulence exhibited by the isolates might have been observed if the growth chamber had been set at a lower temperature that was less conducive to bacterial pathogenesis. It is also possible that at a higher temperature, all isolates may have been equally virulent. A greater difference in the virulence of the isolates also might have been observed if a lower concentration of inoculum had been used. $P$. апnиa plants inoculated with $10^{3} \mathrm{cfu} / \mathrm{ml}$ of bacteria showed the lowest levels of symptoms, and the symptoms increased in severity with $10^{5}, 10^{7}$, and $10^{9} \mathrm{cfu} /$ $\mathrm{ml}$ (Kalmowitz, 1993). The current study utilized bacterial concentrations of approximately $10^{7}-10^{8} \mathrm{cfu} / \mathrm{ml}$. Using high temperatures that were conducive to bacterial replication and high levels of inoculum may have created abnormally high levels of disease symptoms. If the environment had been a little less favorable for bacterial growth, more groupings in the levels of virulence might have been observed.

\section{References}

Jones, J., Bouzar, H., Stall, R., Almira, E., Roberts, P., Bowen, B., Sudberry, J., Stickler, P. and Chun, J. 2000. Systematic analysis of xanthomonads (Xanthomonas spp.) associated with pepper and tomato lesions. Int. J. Syst. Bacteriol. 50:1211-1219.

Kalmowitz, K. 1993. Temperature influence on the biological control agent Xanthomonas campestris strain MSU and physiological and phenolic changes induced in annual bluegrass (Poa annua L). Ph.D. Thesis. North Carolina State University, Raleigh, USA.

Giordano, P. R., Vargas, Jr., J. M., Detweiler, A. R., Dykema, N. M. and Yan, L. 2010. First Report of a Bacterial Disease on Creeping Bentgrass (Agrostis stolonifera) Caused by Acidovorax spp. in the United States. Plant Dis. 94:922.

Mitkowski, N. A. 2005. First report of bacterial wilt of annual bluegrass caused by Xanthomonas translucens pv. poae in Montana. Plant Dis. 89:1016.

Mitkowski, N., Browning, M., Basu, C., Jordan, K. and Jackson, N. 2005. Pathogenicity of Xanthomonas translucens from annual bluegrass on golf course putting greens. Plant Dis. 89: 
469-473.

Nishino, T., Imaizumi, S., Miyabe, K., Yamada, M. and Goto, M. 1995. Xanthomonas campestris pv. poae as the causal agent of wilt symptoms on Annual Bluegrass in Japan. Ann. Phytopathol. Soc. Jpn. 61:555-561.

Roberts, D. L. and Vargas, J. M. 1984. Bacterial wilt: a potentially devastating threat. Golf Course Management, April 1984:
33:37-41.

Roberts, D., Vargas, J. and Detweiler, R. 1985. Occurrence of bacterial wilt on Pоа аппиа and other turfgrasses. (Abstract). Phytopathology 75:1289.

Schaad, N. W. 1980. Laboratory guide for identification of plant pathogenic bacteria. APS, St. Paul, USA. 69 pp. 